\title{
FRAGILE FAMILIES AND WELFARE REFORM
}

\section{Center for Research on Child Wellbeing} Working Paper \#99-11-FF

\author{
Irwin Garfinkel \\ Sara McLanahan \\ Kristen Hark nett
}




\title{
FRAGILE FAMILIES AND WELFARE REFORM
}

\author{
By \\ Irwin Garfinkel \\ Columbia University \\ Sara McLanahan \\ Princeton University \\ and \\ Kristen Harknett \\ Princeton University
}

This paper was prepared for the Conference on "For Better and For Worse: State Welfare Reform and the Well-Being of Low-Income Families and Children" sponsored by the Joint Center for Poverty Research, Washington D.C., September 16-17. Support for Fragile Families and Child Wellbeing study comes from NICHD (grant \#\}, the Ford Foundation, the Robert Wood Johnson Foundation, the Public Policy Institute of California, the Hogg Foundation, the Lowenstein Foundation, the Commonwealth Fund, the Fund for New Jersey, the St. David's Hospital Foundation, New Jersey Healthcare Foundation, W.T. Grant Foundation, the Foundation for Child Development, the Kronkosky Foundation, the California Healthcare Foundation, and the Packard Foundation. 


\section{FRAGILE FAMILIES AND WELFARE REFORM}

\section{Introduction}

The Personal Responsibility and Work Opportunity Reconciliation Act of 1996 (PRWORA) is designed to shift more of the responsibility for poor children from government to parents. To accomplish this goal, the new law requires welfare clients to work and limits the total number of years they can receive assistance. In addition, the new legislation requires unwed fathers to establish paternity and strengthens child support enforcement among nonresident fathers.

Although many people believe that poor children would be better off if their mothers worked and their fathers were more involved in their upbringing, the scientific evidence for these assumptions is weak. We know very little about the ability of poor parents to support their children, and we know even less about their ability to cooperate with one another. Whether recent welfare reform is good public policy will depend in large part on the answers to the following questions:

- What are the conditions and capabilities of low-income parents, especially fathers?

- What is the nature of the parents' relationships in low-income families? How many couples are involved in stable, long-term relationships? How many fathers want to be involved in raising their children?

- How are policies being implemented at the local level? How will they affect parents' capabilities and relationships? And how will they affect child wellbeing?

This paper describes a new study - Fragile Families and Child Wellbeing - that is uniquely suited to answer these three questions.1 The study is designed to follow a new 
birth cohort of approximately 4800 children, including 3675 children born to unmarried parents and 1125 children born to married parents, in 21 cities throughout the United States. The data will be representative of all non-marital births in U.S. cities with populations of 200,000 or more. We use the term fragile families to describe unwed parents and their children to underscore the fact that they are families and to remind the reader that they are vulnerable because of their economic status.

Although the Fragile Families and Child Wellbeing study is designed to provide information on unwed parents and their children, these data will be an excellent resource for examining the effects of welfare reform for several reasons. First, unwed mothers have the highest rates of welfare use of all mothers, and therefore they will be disproportionately affected by welfare reform (Bane and Ellwood 1994). Second, unwed fathers are less likely to live with their children than other fathers, and thus they will be disproportionately affected by the changes in paternity and child support legislation. Third, the new survey interviews both fathers and mothers which will allow researchers to examine parents' capabilities and relationships from two perspectives. And finally, data are being collected in 21 cities with very different welfare and child support policies and different labor market characteristics which will allow researchers to examine the effects of different types of welfare regimes on parents' capabilities and relationships and, ultimately, on child wellbeing.

The next section of the paper discusses the importance of the three questions and describes the state of our current knowledge on these topics. The third section describes the study and the data. The fourth section describes the policy and labor market environments in the first seven cities where we are collecting data. The fifth section 
presents findings from 2 cities - Austin, Texas and Oakland, California. And the last section presents preliminary conclusions.

\section{The Questions}

\section{The Conditions and Capabilities of Poor Parents}

To assess the impact of welfare reform on families and children, we need to know more about the capabilities of the mothers who depend (or would have depended) on cash assistance and the fathers who are expected to provide more child support. Fortunately, we know quite a bit about the capabilities and conditions of poor single mothers, since many of our existing data sets include these women in their samples. We are woefully ignorant, however, about the capabilities of low-income fathers, since many of these men are either non-resident fathers or are loosely attached to their child's household. Policy makers are particularly interested in two aspects of fathers' capabilities - their earnings capacity and their propensity for violence. These two factors are fundamental to the success or failure of the new welfare and child support laws.

The first question facing policy makers is whether non-resident (and loosely attached) fathers can afford to provide more economic support for their children than they currently provide. To date, our best estimates indicate that non-resident fathers are younger, less educated, and less likely to work than resident fathers. Non-resident fathers also report more disability, depression, and drug and alcohol use than married fathers. Not surprisingly, the fathers who live apart from their children have lower incomes than co-resident fathers, and the gap is especially wide among men at the very bottom end of the income distribution (Garfinkel, McLanahan, \& Hanson 1998). The 
latter finding is particularly worrisome for policy makers since low-income men are most likely to be the fathers of children on welfare.

A second question facing policy makers is whether non-resident (and loosely attached) fathers are potentially dangerous. Clearly, most mothers and children would be better off economically if fathers paid more child support. However, some advocates for women fear that forcing fathers to pay child support may have serious negative consequences. Much of this concern is grounded in the belief that a substantial number of non-resident fathers have serious problems with physical abuse and violence. Four recent studies suggest that domestic violence among poor women and women on welfare is very high, with current prevalence ranging from $15 \%$ to $32 \%$ and lifetime prevalence ranging from 34\% to 65\% (Raphael and Tolman 1997).2

All of our estimates of fathers' earnings and capabilities are seriously limited by the fact that many of these fathers are under-represented and under-reported in our national and local surveys.3 Garfinkel and his colleagues (1998) estimate that as many as 3.8 million non-resident fathers are not represented in the National Survey of Families and Households which is arguably the best data we have for studying family relationships. These researchers found that about a third of the "missing fathers" were not in the sampling frame, including fathers in prison, fathers in the military, and, fathers who are part of the census undercount (i.e. homeless men and other individuals who are loosely attached to households). The other two thirds were in the survey, but did not acknowledge their status. The problem is particularly serious for low-income fathers and for men who father children outside marriage (also see Rendall, Clarke, Peters, Ranjit, \& Verroponlou 1997). 
The Fragile Families and Child Wellbeing study will provide better information than previous studies on the earnings and personal problems of unwed fathers, most of whom are or will be non-resident fathers. First, the fathers in the sample will be more representative of unwed fathers because the study starts with a birth and identifies a specific universe of unwed fathers. Second, the information in the new survey will be more accurate than the information in previous studies because fathers will be interviewed directly and followed over time. And finally, the information will be more complete because data on all fathers will be collected from mothers which means that we will know something about the characteristics of the men who do not participate in the study.

\section{Relationships in Fragile Families}

Relationships in fragile families between the father and the mother and the father and the child are especially important to evaluating the effects of welfare and child support reforms. Parents who are in a stable romantic relationship and parents who want to raise their child together will be better able to cope with the demands placed upon them by the new welfare and child support legislation than parents who are not in stable relationships and who cannot cooperate. The latter are likely to experience much more stress and conflict as a result of welfare reform as compared with the former.

Demographers estimate that about $40 \%$ of unwed parents are living together when their child is born (Bumpass and Lu 1998). Another 30\% of unwed fathers see their child at least once a week or more (McLanahan et al. 1998). These figures suggest that relationships in fragile families are converging with those in European countries where 
the vast majority of unwed parents live together in "marriage like" relationships.

The ethnographic literature presents a conflicting picture of the nature of relationships between unwed parents. Anderson (1989) describes how young, inner city men exploit young women in order to satisfy their sexual needs and gain status with their peers.4 In contrast, Edin (1997) suggests that, in many instances, mothers refuse to marry the fathers either because the men are seen as unreliable breadwinners or because they have serious problems with drugs or alcohol. These two stories are different with respect to which parent is making the decision. They are quite similar, however, with respect to the fact that marriage is not part of the future. Other researchers present a more cooperative picture, suggesting that many unwed couples start out with high hopes for maintaining a stable relationship only to find that they (or their partners) cannot meet their earlier expectations. (Edin and Lein 1997, Furstenberg et al. 1992). In his famous study of street-corner life, Leibow (1967) argues that men who are unable to provide economic support for their families disengage as a way of minimizing feelings of inadequacy.

Many of our ideas about the relationship between unwed fathers and their children come from research on divorced and separated fathers. According to this literature, most non-resident fathers do not provide adequate or regular child support and do not maintain regular contact with their child. Moreover, financial support and visitation are known to fall off rapidly over time among divorced fathers. Whereas formal child support agreements are even less common among never married fathers as compared with formerly married fathers, informal support, especially the purchase of goods and services for the child, appears to be very common (Edin and Lein 1997, Waller 1997, Marsiglio 
and Day 1997). Father-child contact is also quite high. Analyses of the NLSY-CS data suggest that half of non-resident, unwed fathers see their child at least once a week and that most of these relationships are quite stable (McLanahan et al. 1997). The high level of involvement among new unwed fathers is probably due to the fact that many of these men are still romantically involved with the mothers. Thus the comparison with divorced and separated fathers may not be appropriate. When and if the relationship with the mother ends, the unwed fathers' involvement may drop off rapidly, as it does among divorced fathers.

The Fragile Families study will collect information from both parents about their views of marriage and cohabitation and their ability to co-operate. The survey will also collect information on parents' expectations about fathers' rights and obligations and about the extent and nature of father/child relationships. These new data will allow researchers to determine if unmarried parents are able to engage in co-operative parenting or if such co-operation is a desirable goal that is simply beyond their reach.

\section{Welfare, Child Support, and Labor Market Regimes}

Economic theory and common sense suggest that low welfare benefits, strict child support enforcement, and strong labor markets promote marriage (Garfinkel and McLanahan 1986). Generous welfare benefits limited to single mothers undermine marriage and promote out-of-wedlock childbearing both by making women more able to afford to be lone mothers and by reducing the gains from marriage. Strict child support enforcement in the presence of a welfare system increases the costs to fathers of living apart from their child more than it increases the benefits to mothers.5 Poor employment 
opportunities for men undermine marriage by making males less attractive and reliable husbands. To the extent that poor employment prospects discourage marriage more than childbearing, they promote out-of-wedlock births. The magnitude of these effects is an empirical question of great practical concern.

Previous research suggests that higher welfare benefits modestly increase single parenthood. (For reviews see Garfinkel and McLanahan 1986, Moffitt 1992, and Moffitt 1998). There is also an emerging body of research that finds that stringent child support enforcement reduces marital disruption (Nixon 1997), and out-of-wedlock childbearing (Case 1998, Garfinkel, Gaylin, Huang, and McLanahan 1998, Plotnick, Garfinkel, Gaylin, McLanahan, and Ku 1998). Previous research has not addressed the question of whether welfare generosity and child support enforcement interact. This is an important question because an interaction between two relatively modest effects could produce a large effect. Finally, obtaining reliable estimates of the labor market effects on marriage has been difficult. Wilson (1987) argues that the decline in marriage among black men is due largely to their declining opportunities in the labor market. Lichter et al. (1991) and Mare and Winship (1992) find some support for the Wilson hypothesis. However, they also find that declining employment accounts for only about $20 \%$ of the decline in marriage. Moreover, as Schultz (1994) argues, it is difficult to disentangle the positive effects of earnings on marriage from the positive effects of marriage on earnings (Korenman and Neumark 1991). By concentrating observations in cities with vastly different welfare, child support, and labor market regimes, by following parents over time as labor markets change, and by measuring other determinants of cohabitation and marriage, the Fragile Families study will allow 
researchers to identify the separate and interactive effects of welfare, child support, and labor markets.

These new data will also provide important information about how recent changes in welfare and child support policies affect parents capabilities and relationships. PRWORA is designed to reduce welfare dependence by forcing mothers into the labor force and by forcing fathers to assume financial responsibility for their children. These changes are likely to provide stronger incentives for parents to remain together. Mothers on welfare who are required to work may prefer to live with their child's father, rely on his income, and stay at home; other mothers may want to live with the father, rely on his income, and supplement the family's income by working part time. A mother on welfare will also have a stronger incentive to live with the child's father if she believes that he will be able to provide long-term economic support beyond the new five-year time limit. Similarly, some fathers who find it difficult to avoid paying child support under the new rules for establishing paternity may decide to live with the mother and child rather than pay child support. Fathers, like mothers, may also be concerned about the economic wellbeing of their child beyond the five-year time limit. Of course, other fathers may make a more determined effort to evade the child support enforcement system. In short, we believe there will be stronger incentives under the new rules for mothers to live with the fathers of their children, and stronger incentives for at least some fathers to live with the mothers and children.

If these hypotheses are correct, and if parents who live together produce an environment for better child outcomes, we would find that strong enforcement of welfare and child support regulations improves the wellbeing of children. On the other hand, it is 
possible that stronger enforcement of both welfare and child support regulations will simply further impoverish both mothers and fathers and/or increase parental conflict, leaving children worse off. By concentrating observations in cities with extreme child support and welfare environments, the Fragile Families survey will facilitate the detection of these interaction effects.

\section{The Design of the Study}

Data for the Fragile Families and Child Wellbeing study is being collected in 21 U.S. cities, stratified by labor market conditions, welfare policies, and child support policies. The geographical dispersion of the cities is depicted in the map of the U.S. in Figure 1. The sample is representative of non-marital births in each city and is representative of all non-marital births to parents residing in cities with populations over 200,000. A comparison group of married parents is also being followed. The total sample size is approximately 4800 families, including 3675 unwed couples and 1125 married couples.

New mothers are interviewed at the hospital within 24 hours after they have given birth. Based on data collection so far, we also expect to interview between 50 and 60 percent of the unmarried fathers at the hospitals. The rest of the fathers will be interviewed as soon as possible after the birth. Follow-up interviews with both parents will be conducted when the child is 12 months, 30 months, and 48 months. Data on child health and development will be collected each year from the mother. In addition, in-home assessments of child wellbeing will be carried out at 48 months.

The baseline questionnaires for mothers and fathers include sections on (1) 
prenatal care, (2) mother-father relationships, (3) expectations about fathers' rights and responsibilities, (4) attitudes toward marriage, (5) parents' health, (6) social support and extended kin, (7) knowledge about local policies and community resources, and (8) education, employment, and income. Follow-up interviews will gather additional information on (1) access to and use of health care and child-care services, (2) experiences with local welfare and child support agencies, (3) experience with the criminal justice system, and (4) parental conflict and domestic violence.

The national sample includes sixteen cities chosen on a random stratified basis from all cities with populations over 200,000. Prior to random selection, cities were ranked according to the generosity of their welfare grants, the strictness of their child support systems, and the strength of their labor markets. Cities with extreme values (in the top or bottom third of the distribution) on all three indicators were placed into one of eight cells $(111,333,331,311,313,131,113,133)$. Cities that fell in the middle third on one or more indicator were placed in the ninth cell. One city was selected randomly from each of the eight extreme cells, and eight cities were selected randomly from the remaining cell.

As originally conceived, the sample size was to be 325 births (250 non-marital and 75 marital births) in the 8 extreme cells, and 100 births (75 non-marital and 25 marital births) in the $9^{\text {th }}$ cell. Additional funding from several foundations allowed us to increase the number of cities with 325 births from 8 to 14 . In order to save money, we cut back the sample size in two of the original cities from 325 to 100 . We did this in cities where we had added foundation cities in the same cell and felt that our ability to detect the high-order interaction effects would not be jeopardized by reducing the number of 
cases. Ultimately, the Fragile Family data include 12 cites with 325 births and 9 cities with 100 births.

Several features of the design merit a more extended discussion: sampling from births, interviewing in the hospitals, and concentrating observations in cities with extreme environments. Sampling from births is excellent way of obtaining a representative sample of children born outside marriage and their parents. Such a sample is ideal for addressing our first and second questions regarding the capabilities and relationships of unwed parents. Interviewing in the hospital is efficient both in terms of reducing time it takes to interview parents and in terms of response rates.6 Though the sample of fathers is only "nearly" representative, the sample of mothers allows us to assess the severity of the "missing fathers" problem. In order to ascertain the extent to which the fathers in the sample are a select sample of unwed fathers, the mothers were asked a series of questions about the fathers of their child, including questions about earnings and domestic violence.

There are three reasons for concentrating observations in cities with extreme environments. First, city environments vary dramatically in a number of ways that are likely to affect individual behavior and family relationships. The effects of environmental influences such as welfare and child support policies, labor markets, sex-ratios, and race/ethnic composition are not well understood and could easily interact with one another and with individual level variables in our models. The generosity of welfare, for example, might have a weak effect on marriage in the context of a strong labor market and strong child support enforcement, but a strong effect in the face of a weak labor market and lax child support enforcement. Similarly, in cities with low welfare benefits and low unemployment, individual values with regard to marriage and cohabitation may 
be a very important determinant of cohabitation, whereas in cities with high benefits and high unemployment, values may play little or no role. Having a large sample in cities with extreme conditions allows us to study the processes that determine adult relationships and the effects of these relationships on wellbeing in each city. In effect, we will have eight case studies of extreme cities. Concentrating observations in eight cities will also allow us to test for whether there are differences across cities in the mean values and effects of different variables.

Second, concentrating observations allows us to more accurately describe the environment in each city. This is especially important for measuring welfare and child support regimes. Administrative record data do not provide population-based information, and they are likely to provide inconsistent information on some variables, such as welfare sanction rates. They also provide no information on still other variables, such as knowledge about the welfare and child support systems. Large national data sets like the CPS provide large enough samples in some states to aggregate to the state level. However, our experience with the Child Support Supplement to the CPS (which has 4000 observations per year) indicates that even after pooling 3 years of data we have very large standard errors in most states. Moreover, although welfare and child support policies are made at the state level, these policies are implemented at the local level. Thus, getting an accurate description of the welfare and child support regimes at the city level is important and requires a large number of cases in each city.

Third, the most efficient design for detecting the effects of differences in child support, welfare, and labor market regimes is to concentrate observations in cities with extreme values (i.e. those with the highest and lowest welfare benefit levels and the 
strongest and weakest child support and labor market regimes). By maximizing the variance in these explanatory variables, we minimize the variance of their estimated coefficients.

\section{Welfare, Child Support, and Labor Market Regimes}

In this section we describe the welfare, child support, and labor market regimes in the first seven cities where we are collecting data. We pay special attention to characterizing these cities in terms of their welfare generosity, the strictness of their child support enforcement, and the strength of their labor markets and to locating Austin and Oakland within these continua.

\section{Welfare Regimes}

Table 1 presents data on a number of variables that are indicators of the generosity of welfare in 7 cities. These cities represent the cities in which Fragile Families data have been collected thus far. We present policy data that describe the state as a whole and county-level statistics that indicate how policies are being implemented at the local level. The first row presents data on the maximum benefit for a family of three. We believe that the welfare benefit level is the single best indicator of welfare generosity. For this reason, we used the welfare benefit level to stratify by generosity when selecting our sample of cities. The other indicators presented in Table 1 are for the most part consistent with the state benefit level but substantially enrich the picture.

Table 1 about here

Texas (Austin) and Virginia (Richmond) stand out as the low benefit states, whereas California (Oakland) and Michigan (Detroit) stand out as high benefit states. Pennsylvania (Philadelphia), New Jersey (Newark), and Maryland (Baltimore) fall in 
between. Benefit levels in the continental U.S. ranged from $\$ 120$ in Mississippi to $\$ 639$ in Vermont in 1997 (U.S. Congress, 1998). The seven Fragile Families states span the range of generosity levels.

The second and third rows of the table present local-level child poverty rates and TANF caseloads per 1000 county residents. 7 The caseloads are a product of both the poverty rate and the generosity of benefits. Philadelphia and Baltimore have the second and third highest poverty rates and the two highest caseload rates. Though Richmond has the highest poverty rate its caseload rate is only average because of its extremely low benefit. Austin, with the second lowest poverty rate and the lowest welfare benefit, has by far the lowest caseload rate.

Rows 4 and 5 present the percentage decline in caseloads between 1997 and 1999 and the percent of applications denied in 1998. The decline in caseloads is one bottomline measure of the tightening of welfare over this period, but it may also reflect differences in labor market strength across cities. The denial rate is a crude measure of administrative stringency. What stands out is that the two cities with the largest percentage decline in caseloads are Austin, in the least generous state, and Detroit, in the second most generous state. Austin, Detroit, Baltimore and Oakland also report much higher denial rates than other cities. These figures suggest that some of the most generous cities - Oakland and Detroit - are pursuing "get tough" strategies.

Rows 6,7 , and 8 present data on variations in state time limits and sanctioning policies. The combination of time limits and sanctioning policies is consistent with the generosity of welfare benefits. Austin and Richmond impose the shortest time limits. When both time limits and sanctioning are taken into account, California and Michigan 
have the most lenient policies. Detroit has no time limits whatsoever, and Oakland has no full family sanctions.

Row 9 presents data on the percent of the TANF caseload that is employed. This figure is an indicator of the extent to which the city is enforcing work requirements, but also may be influenced by work incentives and labor market demand. Note that the two low benefit cities - Austin and Richmond - have the lowest and highest proportions of their caseloads working, respectively. Next to Richmond, Oakland had the second highest proportion of the caseload working. Richmond and Oakland have the most generous earnings disregard policies of the seven city/states, which may account for their high rates of employment for TANF recipients.

Finally, rows 10 and 11 present two measures of the extent to which our cities are supporting the work of low-income families outside welfare. In terms of child-care, Detroit and Newark are the most generous cities and Richmond and Oakland are next most generous. Once again, Austin stands out as the least generous. A state earned income tax credit (EITC), which supplements the federal EITC, is only available in Maryland (Baltimore).

In sum, there are interesting variations within the least and most generous city/states. By every measure Austin is the least generous city. It does nothing to enforce or promote work other than providing extremely low benefits and restricting access. Richmond's benefits, though low and also more time-limited than the other cities, are substantially higher than Austin's. Richmond both encourages work within welfare by providing a generous earnings disregard, and it promotes work outside welfare through child care subsidies. Detroit, although a high-benefit city, is like Richmond with respect 
to enforcing work within welfare and promoting work outside welfare. Finally, Oakland provides high benefits, encourages work within welfare (through earning disregards) but does not provide much support in terms of child-care subsidies.

\section{Child Support Regimes}

Although we have secured some city-level data on child support enforcement, we are missing data in some cities and have questions about the reliability of the city data we have obtained. As a consequence, Table 2 presents data on the effectiveness of child support enforcement at the state level. The quality of these data is also questionable (see Guyer et al. 1997).

\section{Table 2 about here}

The past 25 years have witnessed a steady progression of stricter child support enforcement. Major pieces of legislation in 1975, 1984, and 1988 established and strengthened child support enforcement requirements, triggering a steep, upward trend in paternity establishment and child support collections for never married mothers and AFDC recipients. Most recently, in 1996 PRWORA again tightened the screws on child support enforcement. Our data in Table 2 contain indicators of the strictness of child support enforcement systems in our seven states in 1995 through 1997. It is too soon to see the full effects of the 1996 legislation manifested in these numbers. However, it is still possible to get a sense of which states are the strictest and which are the most lenient.

Rows 1, 2, and 3 present data on the number of paternities established in 1995, 1996, and 1997 divided by the number of non-marital births in those years. The paternity establishment numbers are the least reliable indicators in Table 2 for a number of reasons. 
California's numbers are unbelievable because they are counting all married women receiving welfare as having established paternity. [check**]. For this reason, California is not included when we rank cites on strictness of paternity establishment. In all cases there is ambiguity about whether voluntary, in-hospital paternity establishments are included in the counts. This may even vary from state to state, biasing our comparisons. In addition, there are large fluctuations from year to year in some states. This may have to do with the fact that some states are working through a backlog of cases.

Virginia stands out as the strictest state on paternity establishment. Virginia has a high rate of voluntary, in-hospital paternity establishment. In the early 1990s Virginia became very serious about paternity establishment. It is possible that the trend shown from 1995-1997 is a result of working through a backlog of cases.

Next to Virginia, Pennsylvania has the highest paternity establishment rate. Because paternity may be established for children up to the age of 18 , it is possible that the number of paternities established may exceed the number of out-of-wedlock births if a state made a concerted effort to establish paternity for older children in a given year. Nevertheless, we are skeptical of the 1997 rate in Pennsylvania, which far exceeds 100 percent. The remaining states have similar rates of paternity establishment.

The percent of TANF cases with a child support collection is the most important measure in Table 2, because it is likely to have the biggest effect on the relationship between the parents in the Fragile Families sample. If the collection rate is high, we would expect unmarried parents to have an incentive to unite. We have confidence in these numbers because states must track the number of cases with collections for administrative purposes, and the number of TANF cases in the denominator is also a 
reliable number. Virginia, Michigan, and Pennsylvania stand out as the strictest states. Texas stands out with the lowest collection rate.

Cases with collections (out of all eligible mothers in the state) measure the strength of child support enforcement in the state as a whole. Since these numbers are based on the Current Population Survey (CPS) sample, we have more faith in numbers for large states. Virginia has the highest rate, and Pennsylvania and Maryland are the next best. The rest of the states are slightly lower. Texas does not stand out as lowest on this measure.

The effectiveness ratio is a measure of the effectiveness of the Child Support Enforcement system in a state - i.e., how much child support was actually collected relative to an estimate of what could be collected with perfect enforcement. Here, Virginia and Maryland have the highest effectiveness ratios, and California has the lowest.

In summary, Virginia emerges as the state with the strictest child support enforcement regime on all measures. Pennsylvania, Michigan, and Maryland each had relatively strict enforcement according to some of the measures. Texas and California were generally the most lenient.

\section{Labor Markets}

Table 3 presents data for our 7 cities and the U. S. as a whole on two indicators of labor market performance: unemployment rates in 1997, 1998, and 1999, and employment growth between 1997 and 1999. The economy in general was strong from 1997-1999 in the nation as a whole, and in the seven Fragile Families cities. The U.S. 
unemployment rate fell from 4.9 percent in 1997 to 4.4 percent in 1999, and employment grew by 2.6 percent. Austin, Richmond, and Oakland all have very tight labor markets. But, there is still quite a large difference between Oakland and Austin. If Oakland's labor market is tight, Austin's is extremely tight. Only Newark has a higher unemployment rate and lower employment growth rate than the national average, but employment growth rates in Philadelphia, Baltimore, and Detroit are all below the national average.

\section{Table 3 about here}

\section{Interactions and Extremes}

Austin, Richmond, and Oakland represent extreme environments in terms of all three dimensions: welfare, child support, and labor market. Austin has low welfare, lax child support enforcement, and negligible unemployment. Richmond also has low welfare and unemployment--though neither is quite as extreme as in Austin. But when it comes to child support enforcement, Virginia and Texas are opposites. Like Austin, Oakland has lax child support enforcement and low unemployment--though Oakland's labor market is not as phenomenally robust as Austin's. But, when it comes to welfare, California and Texas are opposites. The extreme contrasts in these environments are important for they allow us to test whether such differences make a difference. For example, to the extent that low welfare, low unemployment and strong child support enforcement promote work, co-habitation, and marriage amongst unwed couples, we would expect to find more work, co-habitation, and eventually marriage among unwed parents in Austin than in Oakland. 


\section{Results from Survey Data in Austin and Oakland}

In this section we present data from the Fragile Family baseline interviews in Austin, Texas and Oakland, California.8 We are currently in the field in five additional cities - Baltimore, Detroit, Newark, Philadelphia, and Richmond - but these data are not ready to be analyzed at present. We use data from Austin and Oakland to address questions about parents' current incomes and sources of economic support, the capabilities of both unwed mothers and fathers, and the relationships between the parents. We present the data separately for couples who are cohabiting, not cohabiting but romantically involved, and no longer romantically involved. Results by relationship status are from pooled (unweighted) data from both cities.

Before presenting the results, it is useful to describe the race/ethnic composition and nativity status of our samples in Austin and Oakland. In Austin, the sample is over $50 \%$ Hispanic, nearly $30 \%$ black, and nearly $20 \%$ white. In Oakland, the sample is over $50 \%$ black, over $30 \%$ Hispanic, and only $3 \%$ white. Compared to the nation as a whole, where about half of unwed births are to white parents, $30 \%$ to black parents, and less than $20 \%$ to Hispanic parents, Oakland and Austin have relatively few unwed white births. These two cities also have higher proportions of immigrants than the rest of the country: one fifth of the Austin sample and nearly one third of the Oakland sample are immigrants.

Table 4 presents data on the incomes and sources of support of new unwed mothers. First, we discuss the findings for all unwed mothers in each city. Then we discuss variations by relationship status. In both cities incomes are low: slightly more than half the households in each city are poor. Mean personal and household income is 
higher in Oakland than in Austin. Lower household income in Austin is traceable to the much larger proportion of very poor households (below $50 \%$ of the poverty line) $-27 \%$ versus $16 \%$. Austin has a much larger proportion of households with incomes above $200 \%$ of the poverty line- $25 \%$ versus $15 \%$. Some of this difference may be due to a peculiarity of the Oakland sample. Oakland residents who belong to the Kaiser health care system give birth in a Kaiser hospital located outside Oakland, and therefore are not included in our sample. While this omission primarily affects marital births, it is likely that some portion of the top part of the unwed birth distribution in Oakland is also missing because they gave birth in this "suburban" hospital.

Table 4 about here

Welfare use is common in both cities, but higher in Oakland than in Austin. Over half of the mothers received AFDC or Food Stamps. Higher welfare benefits as well as more common receipt of benefits undoubtedly help account for the lower rate of extreme poverty in Oakland. Other government transfers, housing assistance, and Medicaid are also all more common in Oakland than in Austin. Medicaid paid for the cost of the child's birth in over $90 \%$ of non-marital births in Oakland. In Austin, the figure is only $65 \%$, but $26 \%$ of the Austin unwed mothers (not shown in table) had private insurance. Type of insurance is another indicator of the social class of unwed mothers in Austin.

Assistance from the mother's family is even more common than welfare in Austin, and nearly as common as welfare in Oakland. Indeed, in Austin more than three quarters of the mothers receiving welfare also received help from their relatives, while in Oakland the proportion was just under a half (not shown in table.) Even more striking is that the most common form of all assistance for unwed mothers is financial support from 
the father of the child. Over three-quarters of the mothers received financial assistance from their child's father. For married couples, this pattern is exactly what we would expect. That the patterns hold for unwed couples, at least during pregnancy, is noteworthy. Also noteworthy and a bit puzzling is the fact that financial support from fathers is 11 points higher in Oakland than in Austin.

Most, but not all, of the difference across relationship statuses are expected. Before discussing these findings, however, it is useful to note that $51 \%$ of the couples were cohabiting at birth, another $30 \%$ were romantically involved and living apart, and $19 \%$ were no longer romantically involved. (The importance of these relationship status findings and variations across cities are discussed below in conjunction with Table 3.) Household income is higher and poverty is lower among unwed mothers who co-habit with the fathers of their children. Similarly assistance from government and the mother's family are lower and assistance from fathers is higher amongst cohabiting mothers. Finally, $80 \%$ to $93 \%$ of the mothers who are romantically involved receive financial assistance from the father as compared to just over $20 \%$ of the mothers who are no longer romantically involved. Surprising to us, at least, is the fact that nearly half of the cohabiting mothers receive AFDC or Food Stamps. (In the baseline questionnaire we did not distinguish between AFDC and Food Stamps.)

So, what are the implications of these findings for welfare and child support policy? First, the numbers suggest that a majority of unwed mothers will be affected by welfare reform and will potentially lose cash resources. Second, the child support provisions in PRWORA may also reduce, rather than increase, the resources available to at least a large minority of unwed mothers. Among unwed mothers who cohabit and 
receive cash assistance - about 50 percent - half (or a quarter of all single mothers) stand to lose resources because of stronger child support enforcement. These mothers are already sharing the father's income, and the child support collected from their partners will go to the state rather than to them. Second, an even larger group of mothers who are not cohabiting but who receive TANF or Food Stamps are also likely to lose resources because of stronger child support enforcement, at least in the short run. We know that $60 \%$ of these mothers received support for the father during pregnancy and if fathers substitute formal child support for informal support the mothers are likely to be worse off. Third, that over half of the mothers who received welfare also received financial help from their families both tells us that families are already providing support which raises the question of whether they can or will do more. This question can only be answered with follow-up data. In the next table, however, we examine mothers and fathers capacities to make up for the cuts in welfare.

\section{Table 5 about here}

Table 5 presents data on the capabilities of unwed mothers and fathers in Austin and Oakland. Because we were able to interview only $75 \%$ of the unwed fathers, fatherreports may be biased. With the exception of wage rates, therefore, we use the mothers' reports to measure fathers' capabilities. (The agreement between mothers' and fathers' reports is quite high for couples for whom we have two interviews.) Both mothers and fathers are relatively young: $60 \%$ of the mothers and $46 \%$ of the fathers are below age 25 . Of even greater concern, nearly half the mothers and almost $40 \%$ of the fathers have not completed high school. Slightly less than one quarter of the parents have education beyond high school. None of this information bodes well for parents' ability to support 
themselves and their new babies. On a more positive note, only a small proportion of either mothers or fathers report serious health problems or problems with alcohol or drugs. Most of the mothers and fathers have had some work experience, but $12 \%$ and $5 \%$ respectively of the mothers and fathers have never worked. Finally, the median wage rate is low-- $\$ 6.25$ and $\$ 8.00$ per hour respectively for mothers and fathers. Not shown in the table, only one quarter of the mothers earn $\$ 8.00$ or more per hour and only one quarter of the fathers earn $\$ 10.00$ or more. In sum, the capacities of these unwed parents to support themselves and their families vary, but on the whole are limited.

The city differences in capabilities are interesting. While the mothers and fathers in Austin are somewhat younger than those in Oakland, they also are better educated, healthier, and more likely to have worked during the last year. The differences in employment rates are particularly interesting. Both the lower level of welfare and the tighter labor market in Austin lead to higher employment rates. At this point, with only two cities to compare, it is impossible to disentangle the effects of welfare from those of the labor market, but these differences whet the appetite for the full Fragile Family sample. (The employment rate differences could also be due to differences in human capital or to differences in sampling across the two cities.) Finally, note that wage rates of fathers are lower in Austin than Oakland, but that the reverse is true for the mothers. Given differences in the cost of living between the two cities, we would expect higher wage rates in Oakland. The higher wage rate for mothers in Austin may be attributable to their greater labor market experience.

The capabilities of the parents, with two notable exceptions, vary in expected ways by relationship status. Not surprisingly, cohabiting parents are somewhat less likely 
to be under twenty and somewhat more likely to be over thirty than non cohabiting parents, but the differences are pretty small. Both the mothers and fathers who cohabit are better educated than those who are romantically involved and living apart; but, surprisingly, the best educated parents are those who are not romantically involved. It will be interesting to see if this relationship holds up in other cities. As expected, fathers who are no longer involved with the mother are less healthy, more likely to have a health problem that limits their work, and more likely to have a problem with alcohol or drugs than involved fathers.

The most striking finding in the table is the variation in fathers' employment rates by relationship status. The percentage of fathers employed last year is $88 \%$ for cohabitors, $77 \%$ for fathers who are romantically involved with the mother, and only $49 \%$ for fathers not romantically involved. Note that cohabiting mothers also work more than mothers who do not cohabit. Finally, it is also surprising that the hourly wage rates of cohabiting fathers are no higher than the wage rates of fathers who do not cohabit. This result may be attributable to non-response bias. We interviewed approximately $90 \%$ of unwed cohabiting fathers, $60 \%$ of romantic fathers, and only $35 \%$ of fathers nonromantic fathers. [check **] If the fathers we interviewed had higher wage rates than those whom we did not interview, the wage rates of the romantically involved and no longer romantically involved fathers would be too high.

Table 6 about here

Table 6 presents data on the relationships, prospects for marriage, and fatherinvolvement. As described above, slightly more than half of unwed parents are cohabiting at the time their child is born, and another $30 \%$ are romantically involved with each 
other. Nearly $70 \%$ of the mothers believe they have a fifty-fifty chance or better of marrying the fathers and a similar number believe that marriage is better for kids. An even larger percentage of mothers report that the father's name will be on the birth certificate, that the child will have the father's surname, and that the father provided financial support during pregnancy and visited the mother and child in the hospital. Ninety one percent of the mothers say they want the father involved in raising the child!

The proportions are even higher for fathers' reports. (The father reports are upwardly biased because fathers who are interviewed are likely to be more committed to their children than fathers who are not interviewed. But in cases where both the mother and father are interviewed, they report similar high values.) Finally, nearly $100 \%$ of the fathers interviewed agreed or strongly agreed with the statement that "Losing a chance to be part of my child's life would be one of the worst things that could happen to me." In short, the overwhelming majority of the mothers and fathers in fragile families have high hopes and good intentions.

Variations by city and relationship status are once again quite interesting. Austin, as compared to Oakland, has a higher proportion of cohabiting parents -- 56\% versus $47 \%$-- but a lower proportion of parents who are romantically involved (77\% versus $87 \%$ ). Consistent with the lower proportion of romantically involved couples, Austin mothers and fathers also report lower father-child involvement. Not surprisingly, the variation by relationship status is far more dramatic. Of mothers who cohabit, over $90 \%$ expect to marry the father, among those not cohabiting but romantically involved, nearly $70 \%$ expect to marry the father, but only $4 \%$ of those no longer romantically involved expect to marry the father. The cohabiting and romantically involved fathers are a bit 
more optimistic. Quite surprisingly, nearly half of the non-romantic fathers retain high hopes of marriage. No doubt these high hopes contributed to their willingness to be part of our study. Note that among the fathers who are no longer romantically involved, the proportion of men who said they would help support the child is larger than the proportion who actually provided support during the pregnancy, suggesting that talk is "cheap."

\section{Conclusions}

From our initial exploration of the Fragile Families and Child Well-Being data two findings stand out. First, unwed parents in both cities are highly committed to each other and to their children, at least initially. Half of unwed parents live together, and another $30 \%$ are romantically involved with each other. More than two thirds expect to marry. Eight out of ten fathers provided support during the pregnancy, and more than eight of ten mothers plan to put the father's name on the birth certificate. The overwhelming majority of mothers want the father to be involved in raising their child. The challenge for policy makers and community leaders is to nourish rather than undermine these commitments.

Second, most unmarried parents in both cities are poorly equipped to support their families. The typical father has an income of less than $\$ 12,500$ dollars a year and the typical mother has only $\$ 4000$ to $\$ 5000$. The human capital of both parents is low. Nearly half of mothers and fathers lack a high school degree. Less than $20 \%$ have more than a high school degree. In Oakland, nearly one out of four fathers and two out of five mothers did not work in the previous year. Increases in human capital, employment, and 
earnings are likely to play critical roles in the success or failure of parents in maintaining stable families.

Finally, although it is too early to draw conclusions about how policy regimes affect parents' relationships and capabilities, our initial examination of state and city policies indicate that PRWORA is a heterogeneous set of initiatives that are being implemented under very different labor market conditions. At one extreme are cities like Richmond, Virginia, where welfare benefits are low, time limits and work requirements are strict, child support enforcement is strong and unemployment rates are low. At another extreme are cities like Oakland, California where welfare benefits are high, time limits and work requirements are weak, child support enforcement is weak, and unemployment rates are higher. When we revisit the parents in these two cities in 12 months, we would expect to find more working parents and more marriage and cohabitation in Richmond than in Oakland. With data from 20 different policy regimes, we will soon able to bring empirical evidence to bear on these predictions. 


\section{BIBLIOGRAPHY}

Anderson, E. 1989. Sex codes and family life among poor inner city youths. Annals of the American Academy of Political and Social Science, 501:59-78.

Bane, M. J., and Ellwood, D.T. 1994. Welfare Realities: From Rhetoric to Reform. Cambridge, MA: Harvard University Press.

Bumpass, L. and Lu, H.H. 1998. Trends in Cohabitation and Implications for Children's Family Context in the U.S. CDE Working Paper \#98-15. University of Wisconsin, Madison Wisconsin.

Case, A. 1998. The effects of stronger child support enforcement on non-marital fertility. In Fathers Under Fire: The Revolution in Child Support Enforcement. New York: Russell Sage Foundation.

Cherlin, A., et al., 1983. Cherlin, A, Griffith, J. and McCarthy, J. 1983. "A Note on Maritally-Disrupted Men's Reports of Child Support in June 1980 Current Population Survey." Demography 20(3): 385-89.

Cherlin, A.J. and Furstenberg, F.F. 1991. Divided Families. Cambridge: Harvard University Press.

Conlisk, J., and Watts, H. 1969. A model for optimizing experimental designs for estimating response surfaces, Proceedings of the Social Statistics Section, American Statistical Association, 150-156.

Edin, K. 1997. Why don't poor fathers and mothers get married? Paper presented at the Urban Poverty Workshop, University of Chicago, March 1997.

Edin, K. and Lein, L. 1997. Making Ends Meet: How Single Mothers Survive Welfare and Low-Wage Work. New York: Russell Sage Foundation.

Furstenberg, F.F. 1976. Unplanned Parenthood: the Social Consequences of Teenage Parenting. New York: Free Press.

Furstenberg, F.F. and Harris, K.M. 1992. The disappearing American father? Divorce and the waning significance of biological parenthood, in S.J. South and S.E. Tolnay (eds.), The Changing American Family: Sociological and Demographic Perspectives. Boulder, CO: Westview Press.

Furstenberg, F.F., Morgan, S.P. and Allison, P.D. 1987. Paternal participation and children's well-being after marital dissolution. American Sociological Review, 52:695-701. 
Furstenberg, F.F., Sherwood, K., and Sullivan, M. Caring and Paying: What Fathers and Mothers Say About Child Support. New York, Manpower Demonstration Research Corporation. July 1992.

Garfinkel, I. and McLanahan, S. 1986. Single Mothers and Their Children: A New American Dilemma. Washington, D. C.: The Urban Institute.

Garfinkel, I., McLanahan, S., and Robins, P. (eds). 1994. Child Support and Child WellBeing. Washington, DC: The Urban Institute.

Garfinkel, I., McLanahan, S., Meyer, D., and Seltzer, J. (eds). 1998. Fathers Under Fire: The Revolution in Child Support Enforcement. New York: Russell Sage Foundation.

Garfinkel, I.; McLanahan, S.; and Hanson, T. 1998. A patchwork portrait of nonresident fathers. In Fathers Under Fire: The Revolution in Child Support Enforcement. New York: Russell Sage Foundation.

Garfinkel, I. et al., 1998. Garfinkel, I., Miller, C., McLanahan, S. and Hanson, T. 1998. "Deadbeat dads or inept states? A comparison of child support enforcement systems." Evaluation Review. 22 (6): 717-750.

Garfinkel, I., Gaylin, D., McLanahan, S. and Huang, 1999. "Will Child Support Enforcement Reduce Nonmarital Childbearing?" Unpublished manuscript

Hofferth, S. L., and Hayes, C. D. 1987. Risking the Future. Vol. II. Washington, DC: National Academy Press.

Korenman, S., and Neumark, D. 1991. Does marriage really make men more productive? Journal of Human Resources 26: 282-307.

Lamb, M. 1986. (ed). The Father's Role: Applied Perspectives. New York: John Wiley \& Sons.

Lichter, D. T., LeClere, F. B., and McLaughline, D. K. 1991. Local marriage markets and the marital behavior of black and white women. American Journal of Sociology 96: 843-67.

Liebow, E. 1967. Tally's Corner: A Study of Negro Streetcorner Men. Boston: Little, Brown and Company.

Mare, R. D. and Winship, Christopher. 1991. "Socioeconomic Change and the Decline of Marriage for Blacks and Whites." in Christopher Jencks and Paul E. Peterson, eds., The Urban Underclass. Washington, DC: Brookings Institution, pp 175-202. 
Marsiglio, W. 1993. Contemporary scholarship on fatherhood: culture, identity and conduct. Journal of Family Issues, 14:484-509.

Marsiglio, W. and Day, R. 1997. Social fatherhood and paternal involvement: Conceptual, data, and policymaking issues. Presented at the NICHD sponsored Conference on Fathering and Male Fertility: Improving Data and Research.

McLanahan, S. and Sandefur, G. 1994. Growing Up With a Single Parent. Cambridge, MA: Harvard University Press.

McLanahan, S., Garfinkel, I., Brooks-Gunn, J, and Zhao, H. (1997). Fragile Families. Unpublished manuscript.

Moffitt, R. 1992. "Incentive Effects of the U.S. Welfare System: A Review." Journal of Economic Literature, (March) 30: 1-61.

Moffit, R. (ed.). 1998. The Effect of Welfare on Mariage and Fertility: What Do We Know and What Do We Need to Know? Welfare, the Family, and Reproductive Behavior. Washington: National Research Council, National Academy of Sciences

Monthly Vital Statistics Report, Vol. 46, No. 1 Supplement. 1996. http://www.cdc.gov/nchswww/fastats/birthwt.htm (4/1/99).

Moore, K. 1995. Births to Unmarried Mothers: United States, 1980-92. Report to Congress on Out-of-Wedlock Childbearing. Department of Health and Human Services.

Morgan, S.P., Lye, D.N., and Condran, G.A. 1988. Sons, daughters, and the risk of marital disruption. American Journal of Sociology, 94: 110-129.

Morris, C.N., Newhouse, J.P., et al. 1980. The Theory and Practice of Obtaining Unbiased and Efficient Samples in Social Surveys, The Rand Coporation.

Nixon, L.A. 1997. "The Effect of Child Support Enforcement on Marital Dissolution." Journal of Human Resources, 32: 159-181.

Nord, C.W., and Zill, N. 1996. Non-custodial Parents' Participation in Their Children's Lives: Evidence from the Survey of Income and Program participation. Rockville: Westat, Inc.

Parke, R.D. 1995. Fathers and families. In M.H. Bornstei andbook of Parenting, Vol. 3: Status and Social Conditions of Parenting. Mahwah, NJ: Erlbaum. 
Plotnick, R., I.Garfinkel, D. Gaylin, S. McLanahan, and I. Ku, 1998. "Better Child Support Enforcement: Can It Reduce Teenage Premarital Childbearing?" Paper presented in Population Association of America 1998 Annual Meeting.

Raphael, J., and Tolman, R.M. 1997. Trapped by poverty and trapped by abuse: New evidence documenting the relationship between domestic violence and welfare: Executive summary. Chicago: Taylor Institute.

Rendall, M.S., Clarke, L., Peters, H.E., Ranjit, N., and Verropoulou, G. 1997. Incomplete reporting of male fertility in the United States and Britain. Paper presented at the annual meeting of Population Association of America, Washington, DC.

Schultz, T.P. 1994. Marital status and fertility in the United States: Welfare and labor market effects. The Journal of Human Resources 29: 636-69.

Seltzer, J.A. 1994. Consequences of marital dissolution for children. Annual Review of Sociology, 20:235-266.

South, S. 1992. For love or money? Sociodemographic determinants of the expected benefits from marriage. In South, S. and Tolnay S. E. (eds) The Changing American Family: Sociological and Demographic Perspectives. Boulder, CO: Westview Press.

Stack, C.B. 1974. All our Kin: Strategies for Survival in a Black Community. New York: Harper and Row.

Tanfer, K. and Mott, F. 1997. The meaning of fatherhood for men. Paper prepared for the working group on male fertility and family formation.

The Urban Institute, Assessing the New Federalism. National Survey of American Families, 1997. http://newfederalism.urban.org/nsaf/income_a3.html (3/1/99)

U.S. Bureau of the Census. State and Metropolitan Area Data Book 1997-98 ( $5^{\text {th }}$ ed.), p. 102-107. Washington, D.C., 1998.

U.S. Bureau of Labor Statistics, Local Area Unemployment Statistics, 1998-99. http://www.bls.gov/news.release/metro.t01.htm. (3/1/99).

U.S. Congress, 1998. 1998 Green Book prepared by the Committee on Ways and Means, United States House of Representatives. Washington: U.S. Government Printing Office, Table 7-14. avail. online: http://aspe.hhs.gov/98gb/intro.htm

U.S. Department of Labor. Bureau of Labor Statistics, Employment and Earnings. Labor Force Status by State and Metropolitan Area. DUDOC L2.41/2: 45/5, p. 168, May 1998. 
Ventura, S.J., Bachrach, C. A., Hill, L., Kaye, K., Holcomb, P., and Koff, E. 1995. The demography of out-of-wedlock childbearing. Report to Congress on Out-ofWedlock Childbearing. Washington, DC: Department of Health and Human Services.

Ventura, S.J., Martin, J.A., Curtin, S.C., Mathews, T.J. Report of Final Natality Statistics, 1996. Monthly Vital Statistics Report, Volume 46, No 11, supplement. Hyattsville, MD: National Center for Health Statistics, 1997.

Waller, Maureen. 1997. Redefining fatherhood: paternal involvement, masculinity, and responsibility in the "other America." Doctoral Dissertation, Princeton University, New Jersey.

Willis, R. 1996. Father Involvement Theoretical Perspectives from Economics. Paper presented at Conference on Father's Involvement. NICHD Family and Child Wellbeing Network. Bethesda, MD.

Wilson, W. J. 1987. The Truly Disadvantaged. Chicago: The University of Chicago.

Wilson, W. J. 1996. When Work Disappears: The World of the New Urban Poor. New York: Alfred A. Knopf. 


\section{ENDNOTES}

1 Sara McLanahan (Princeton University) and Irwin Garfinkel (Columbia University) are principal Investigators. Jeanne Brooks-Gunn (Columbia) and Marta Tienda (Princeton) are co-investigators, and Angus Deaton and Burton Singer are statistical consultants. Nancy Reichman is the Project Director. Other co-investigators include a network of (primarily) minority scholars at seven different universities and research institutes: Sheila Ards at Benedict College, Waldo Johnson at the University of Chicago, Yolanda Padilla at the University of Texas, Lauren Rich at the University of Pennsylvania, Mark Turner at the Urban Institute, Melvin Wilson at the University of Virginia, and Maureen Waller at the Public Policy Institute of California.

2 We must approach these figures cautiously, however, since the statistics are based on special populations (i.e. welfare mothers) and do not distinguish between biological and social fathers.

3 This problem was first identified by Cherlin, Griffith, and McCarthy (1983).

4 Willis (1996) offers an economic explanation for the same behavior. He argues that unmarried women allow men to "free ride" (in terms of supporting their children) when there is a surplus of women and when women have an alternative source of support (e.g. welfare).

5 Though economic theory does not yield general conclusions about the effects of stronger child support enforcement on non-marital births or divorce, in conditions which pertain in the US today, theory predicts deterrence effects. Stronger enforcement increases the income of the custodial or resident parent and reduces the income of the non-resident parent. To simplify, yet account for most cases, we call resident parents mothers and non-resident parents, fathers. If child support enforcement is tougher, mothers will be more prone to parent a child out-of-wedlock and divorce, while fathers will be less prone to do either. Which effect will dominate cannot be ascertained in general. But Nixon (1997) shows that if there is a welfare or public assistance system, theory predicts stronger enforcement reduces divorce. Similarly, Willis (1994) finds that in the presence of welfare and a shortage of males, theory predicts stronger enforcement reduces non-marital births. One simple though not quite full story is that amongst couples where the mother would go on welfare if she had a non-marital birth or divorced, welfare removes or at least reduces the benefit of strong enforcement. Thus the effects of enforcement on the incomes of these mothers and fathers is asymmetrical. In short, previous research suggests that in conditions which pertain in the US today, economic theory predicts stronger child support enforcement will reduce non-marital births and divorce.

6 In the first two cities - Oakland and Austin - we were able to interview about 58 percent of the unmarried fathers at the hospital. 
7 TANF data are not available at the city level. Therefore, we use data at the county level.

8 Each city sample contains 325 families, 250 unmarried couples plus 75 married couples who serve as a comparison group. Data were collected in Oakland at Summit and Highland hospitals from February 14 through June 15, 1998 and in Austin at all birthing hospitals from April 9th through June 30th. Mothers giving birth during this time were approached in the hospitals and asked to participate in the study. Approximately $93 \%$ of the mothers agreed to participate. Mothers were asked to provide locating information on the fathers, and fathers were contacted either in the hospitals or as soon as possible after the child's birth. Approximately $90 \%$ of married fathers and $75 \%$ of unmarried fathers agreed to participate in the study. The mother's interview lasted about 30 minutes and the father's interview lasted 40 minutes. At the time we conducted the survey, women could go to two hospitals in Oakland to deliver a baby (Highland and Summit). However, before 1998, Kaiser Hospital in Oakland also performed deliveries. At the time of the study, women who were Kaiser patients were taken to Alta Bates Hospital in Berkeley for deliveries. 
Table 1

Welfare Indicators for 7 Fragile Family City, States

\begin{tabular}{|c|c|c|c|c|c|c|c|}
\hline & $\begin{array}{l}\text { Austin, } \\
\text { TX }\end{array}$ & $\begin{array}{l}\text { Balt., } \\
\text { MD }\end{array}$ & $\begin{array}{c}\text { Detroit } \\
\text { MI }\end{array}$ & $\begin{array}{c}\text { Newark, } \\
\text { NJ }\end{array}$ & $\begin{array}{c}\text { Oakland, } \\
\text { CA }\end{array}$ & $\begin{array}{l}\text { Phila., } \\
\text { PA }\end{array}$ & $\begin{array}{c}\text { Richmond, } \\
\text { VA }\end{array}$ \\
\hline \multicolumn{8}{|l|}{ State TANF grant amount } \\
\hline for a family of 3, $1997(\$)$ & 188 & 388 & 459 & 424 & 565 & $403^{a}$ & $291^{a}$ \\
\hline $\begin{array}{l}\text { County child poverty rate, } \\
1995(\%)\end{array}$ & \multicolumn{6}{|c|}{ County child poverty rate, } & 41.8 \\
\hline $\begin{array}{l}\text { Number of TANF cases in co } \\
\text { per } 1000 \text { county residents, } \\
1998\end{array}$ & 5.9 & 38.1 & 26.8 & 28.4 & 18.6 & 42.4 & 23.3 \\
\hline \multicolumn{8}{|l|}{ Percent change in county } \\
\hline TANF caseload, 1997-1999 & -36.5 & -26.9 & -32.0 & -20.8 & -20.9 & -19.5 & -19.4 \\
\hline $\begin{array}{l}\text { Applications denied in county } \\
1998(\%)\end{array}$ & 57.3 & 46.9 & 35.2 & 8.5 & 42.3 & 19.1 & 22.5 \\
\hline
\end{tabular}

State Restrictions on eligibility:

Lifetime TANF time limit 1,2 , or 3 yrs $^{b} 5$ years none 5 years 5 years 5 years 2 years $^{c}$ TANF terminated or reduced after time limit terminated $^{d}$ reduced n/a terminated reduced terminated terminated Full familysanctions no yes yes yes no yes yes 


\begin{tabular}{ccccccc} 
Welfare Indicators for 7 Fragile Family & City, States, Continued & \\
Austin, & Balt., & Detroit & Newark, & Oakland, & Phila., & Richmond, \\
TX & MD & MI & NJ & CA & PA & VA \\
\hline
\end{tabular}

County TANF recipients who

who worked, 1998 (\%)

$\begin{array}{lll}4.5 & 17.9 \quad 30.0\end{array}$

$7.9 \quad 39.6$

14.9

48.1

Number of subsidized child care slots

per child under 5 in county

0.02

$0.12 \quad 0.32$

0.33

0.19

0.07

0.18

State offers Earned Income

Tax Credit (EITC)

no yes no

no

no

no

no

Source: Urban Institute, Census web site, and data collected from state or county TANF and child care departments. Notes:

${ }^{a}$ Benefit levels vary by county or city in PA and VA. Amount shown applies to the largest portion of the state.

${ }^{\mathrm{b}}$ Texas assigns time limits based on employability, e.g., those deemed most employable are assigned a 1-year time limit and those deemed least employable are assigned a 3-year limit.

${ }^{c}$ In Virginia, benefits are terminated after 2 years, but a family can reapply after 2-3 years.

${ }^{d}$ In Texas benefits are reduced after the 1, 2, or 3 year limit and terminated after 5 years. 
Table 2

Child Support Enforcement Indicators for 7 Fragile Family City, States

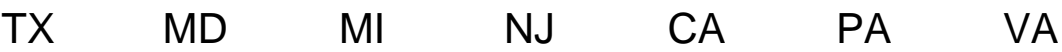
(Austin) (Balt.) (Detr.) (Newk.) (Oakl.) $\quad$ (Phila.) $\quad$ (Rich.)

Paternities established per out-of-wedlock birth

$\begin{array}{rrrrrrrr}1995 & 39.8 & 37.5 & 48.6 & 41.7 & 73.2 & 56.2 & 96.8 \\ 1996 & 43.0 & 45.6 & 55.3 & 46.2 & 108.3 & 61.7 & 71.2 \\ 1997 & 43.5 & 54.1 & 39.7 & 39.6 & 116.4 & 171.1 & 43.0\end{array}$

TANF cases with collections as percent of TANF caseload

$\begin{array}{llllllll}1995 & 11.3 & 27.1 & 39.1 & 33.1 & 18.7 & 36.5 & 64.8 \\ 1996 & 12.9 & 27.9 & 48.0 & 36.9 & 24.9 & 41.3 & 34.3 \\ 1997 & 14.2 & 29.3 & 54.3 & 37.8 & 30.7 & 42.4 & 30.3\end{array}$

Cases with collections as percent of all eligibles in the state ${ }^{a}$

$\begin{array}{rrrrrrrr}1995 & 30.6 & 33.4 & 31.1 & 26.1 & 22.9 & 38.2 & 40.1 \\ 1996 & 32.0 & 36.9 & 30.0 & 24.7 & 23.4 & 35.8 & 48.1 \\ 1997 & n / a & n / a & n / a & n / a & n / a & n / a & n / a\end{array}$

Effectiveness ratio for all eligibles in the state ${ }^{\mathrm{b}}$

\begin{tabular}{rrrrrrrr}
1995 & 17.8 & 24.1 & 16.5 & 16.2 & 11.6 & 17.9 & 24.7 \\
1996 & 17.3 & 24.2 & 17.9 & 16.4 & 10.8 & 18.9 & 21.7 \\
1997 & $n / a$ & $n / a$ & $n / a$ & $n / a$ & $n / a$ & $n / a$ & $n / a$ \\
\hline
\end{tabular}

Sources: Number of out-of-wedlock births are from Vital Statistics. TANF caseload sizes are from the Administration for Children and Families web site. The rest of the numbers are from the Office of Child Support Enforcement's 1995, 1996, and 1997 Annual Reports, and our calculations from the Current Population Survey.

Notes: "All eligibles" is defined as the number of single mothers in the state who are not widows.

${ }^{\mathrm{b}}$ The Effectiveness ratio is the amount of child support collected in the state divided by an estimate of the total amount of support for which single mothers were eligible. 


\section{Table 3}

\section{Labor Market Indicators for 7 Fragile Families Cities}

\begin{tabular}{|c|c|c|c|c|c|c|c|c|}
\hline & $\begin{array}{l}\text { Austin, } \\
\text { TX }\end{array}$ & $\begin{array}{c}\text { Baltim., } \\
\text { MD }\end{array}$ & $\begin{array}{c}\text { Detroit, } \\
\text { Ml }\end{array}$ & $\begin{array}{c}\text { Newark, } \\
\text { NJ }\end{array}$ & $\begin{array}{c}\text { Jakland, } \\
\text { CA }\end{array}$ & $\begin{array}{c}\text { Phila., } \\
\text { PA }\end{array}$ & $\begin{array}{l}\text { Richmd, } \\
\text { VA }\end{array}$ & U.S. \\
\hline \multicolumn{9}{|c|}{ Unemployment rate (\%) } \\
\hline 1997 & 3.2 & 5.6 & 4.7 & 6.5 & 4.3 & 4.9 & 3.5 & 4.9 \\
\hline 1998 & 2.8 & 5.1 & 4.3 & 5.6 & 3.9 & 4.3 & 2.6 & 4.5 \\
\hline 1999 & 2.4 & 4.3 & 4.4 & 5.6 & 3.5 & 4.0 & 2.4 & 4.4 \\
\hline \multicolumn{9}{|c|}{ Employment Growth (\%) } \\
\hline 1997-1999 & 8.4 & 1.1 & 1.9 & 1.5 & 4.3 & 0.7 & 5.9 & 2.6 \\
\hline
\end{tabular}

Source: Bureau of Labor Statistics web site: www.bls.gov

Notes: Labor market statistics are not seasonally adjusted.

County-level labor market statistics are based on a combination of Unemployment Insurance (UI) records and survey (CPS and CES) data. U.S. labor market statistics are based on the CPS. 
Table 4: Mothers Circumstances: Income and Sources of Support

\begin{tabular}{|c|c|c|c|c|c|c|}
\hline & $\begin{array}{l}\text { All Moms } \\
\text { Austin }\end{array}$ & $\begin{array}{l}\text { All Moms } \\
\text { Oakland }\end{array}$ & All Unwed Moms & Cohabiting & Romantic & Other \\
\hline Personal Income & 4000 & 5000 & 4122 & 5000 & 3560 & 4000 \\
\hline Household Income & 14050 & 15772 & 14679 & 16883 & 12971 & 13631 \\
\hline \multicolumn{7}{|l|}{ Poverty Status } \\
\hline$<50 \%$ & $27 \%$ & $16 \%$ & $22 \%$ & $19 \%$ & $25 \%$ & $26 \%$ \\
\hline $50 \%$ to $100 \%$ & $26 \%$ & $40 \%$ & $33 \%$ & $33 \%$ & $32 \%$ & $33 \%$ \\
\hline $100 \%$ to $200 \%$ & $22 \%$ & $29 \%$ & $25 \%$ & $27 \%$ & $24 \%$ & $19 \%$ \\
\hline$>200 \%$ & $25 \%$ & $15 \%$ & $21 \%$ & $21 \%$ & $18 \%$ & $22 \%$ \\
\hline \multicolumn{7}{|l|}{ Government Assitance } \\
\hline$\%$ with AFDC or food stamps & $43 \%$ & $52 \%$ & $48 \%$ & $47 \%$ & $51 \%$ & $46 \%$ \\
\hline$\%$ with other government transfers & $5 \%$ & $13 \%$ & $9 \%$ & $8 \%$ & $13 \%$ & $3 \%$ \\
\hline$\%$ with housing assistance & $17 \%$ & $24 \%$ & $17 \%$ & $14 \%$ & $24 \%$ & $16 \%$ \\
\hline$\%$ with Medicaid & $65 \%$ & $91 \%$ & $78 \%$ & $77 \%$ & $84 \%$ & $72 \%$ \\
\hline \multicolumn{7}{|l|}{ Family Assistance } \\
\hline$\%$ with financial help from family & $58 \%$ & $46 \%$ & $52 \%$ & $44 \%$ & $60 \%$ & $63 \%$ \\
\hline$\%$ with housing from family & $41 \%$ & $44 \%$ & $42 \%$ & $28 \%$ & $56 \%$ & $60 \%$ \\
\hline$\%$ with financial help from dad & $72 \%$ & $83 \%$ & $77 \%$ & $93 \%$ & $80 \%$ & $28 \%$ \\
\hline$\%$ with "other" help from dad & $73 \%$ & $79 \%$ & $76 \%$ & $98 \%$ & $73 \%$ & $19 \%$ \\
\hline
\end{tabular}


Table 5: Capabilities of Mothers and Fathers

Age

$<20$

20-24

25-29

$30+$

\section{Education}

$<$ high school

high school

some college

college degree or more

$\%$ Fair or poor health

$\%$ With drug or alcohol problem

$\%$ Worked last year

Never worked

Hourly wage (median)
All Moms All Moms

Austin Oakland

$\begin{array}{ll}24 \% & 19 \% \\ 45 \% & 34 \% \\ 17 \% & 28 \% \\ 15 \% & 19 \%\end{array}$

$45 \%$

$28 \%$

$22 \%$

$5 \%$

$39 \%$

$1 \%$

$4 \% \quad 19 \%$

$\$ 6.49 \quad \$ 6.00$

\section{$52 \%$}

$31 \%$

$15 \%$

$2 \%$

$41 \%$

$6 \%$
MOTHERS

All Unwed

Moms Cohabiting Romantic Other

$21 \%$

$39 \%$

$23 \%$

$17 \%$

$19 \%$

$26 \%$

$21 \%$

$44 \% \quad 34 \% \quad 34 \%$

$22 \%$

$23 \%$

$23 \%$

$15 \%$

$17 \%$

$21 \%$

$30 \%$

$19 \%$

$3 \%$

$10 \%$

$4 \%$

$68 \%$

$12 \%$

$\$ 6.25$

$54 \%$

$30 \%$

$16 \% \quad 26 \%$

$1 \% \quad 3 \%$

$10 \% \quad 3 \%$

$6 \% \quad 4 \%$

$61 \%$

$15 \%$

$67 \%$

$7 \%$

$\$ 6.00$
$81 \% \quad 55 \%$

$48 \%$

\section{$48 \%$}

$30 \%$

$17 \%$

$5 \%$

$12 \%$

$2 \%$

$72 \%$

$11 \%$

$\$ 6.16$

\section{FATHERS}

All Dads All Dads All Unwed

Austin Oakland Dads Cohabiting Romantic Other

\section{Age}

$<20$

20-24

25-29

$30+$

\section{Education}

$<$ high school

high school

some college

college degree or more

$\%$ Fair or poor health

$\%$ With health problem limit work

$\begin{array}{cc}11 \% & 9 \% \\ 41 \% & 30 \% \\ 24 \% & 29 \% \\ 24 \% & 19 \%\end{array}$

$10 \%$

$36 \%$

$27 \%$

$28 \%$

$$
9 \%
$$

$37 \%$

$25 \%$

$\$ 6.63$ 
Table 6: Relationships and Pertinent Values in Fragile Families

Percent Cohabiting

Percent Romantic

Percent Other

Chance of marriage

(50\% or greater)

Mothers report

Fathers report

Marriage better for kids

(\%Agree or Strongly agree)

Mothers report

Fathers report
All Moms All Moms All Unwed

Austin Oakland Moms Cohabiting Romantic Other

$47 \% \quad 56 \% \quad 52 \%$

$39 \% \quad 21 \% \quad 30 \%$

$14 \% \quad 23 \% \quad 19 \%$

$\begin{array}{lccccc}67 \% & 70 \% & 69 \% & 92 \% & 69 \% & 4 \% \\ 89 \% & 82 \% & 85 \% & 95 \% & 76 \% & 45 \% \\ & & & & & \\ 72 \% & 70 \% & 71 \% & 73 \% & 68 \% & 68 \% \\ 80 \% & 76 \% & 78 \% & 81 \% & 70 \% & 79 \%\end{array}$

Father's name on Birth

Certificate (mother report)

Child will have Father's

Surname (mother report)

Want Father Involved

(mother report)

$\begin{array}{llllll}81 \% & 89 \% & 83 \% & 93 \% & 86 \% & 50 \%\end{array}$

$\begin{array}{llllll}80 \% & 89 \% & 75 \% & 86 \% & 73 \% & 47 \%\end{array}$

$\begin{array}{llllll}89 \% & 92 \% & 91 \% & 100 \% & 94 \% & 60 \%\end{array}$

Father Financial

Contribution During Father Visit Hospital

(mother report)

Fathers Agree to Support

Child (mother report)

$\begin{array}{llllll}72 \% & 83 \% & 77 \% & 93 \% & 80 \% & 28 \%\end{array}$

$\begin{array}{llllll}71 \% & 77 \% & 74 \% & 92 \% & 69 \% & 33 \%\end{array}$

$29 \% \quad 34 \% \quad 31 \% \quad$ N.A.* $\quad 73 \% \quad 38 \%$

Fathers Values Fatherhood

(father report)

$\begin{array}{llllll}99 \% & 97 \% & 97 \% & 98 \% & 96 \% & 97 \%\end{array}$

*Not Applicable - Mothers who report that they live with the father (Q. B20 in mother's questionnaires) are skipped out of this question 